\title{
ANATOMI KEABSAHAN BUNGA BANK DALAM PERSPEKTIF TEORI LIMIT MUHAMMAD SYAHRÛR
}

\author{
Dadang Abdul Qadir \\ Pengamat Hukum dan Reformasi Peradilan Jawa Barat \\ E-Mail: abd_qadir18@yahoo.com
}

\begin{abstract}
Riba is an excess of the capital, which is including all types of loans that used a lot or a little an extra. The majority of Muslim stated that interest and usury (riba) are the same, so that the interest became haram. Nevertheless, Muhammad Syahrûr said that the interest is not usury (riba), for not reaching $100 \%$ of the capital invested. He used a different methodology than the majority of Muslim scholars. He developed his own methodology in making a law. One of them is the theory of limits. The term limits (hudûd) is used referring to the sense of the limits of the provisions of God that should not be violated, but there is a region for ijtihâd which are dynamic, flexible, and elastic. The method used in this paper is descriptive, whereas technical for collecting data is literature study, especially the book written by Muhammd Syahrûr , namely al-Kitâb wa al-Qur'ân: Qirâ'ah Mu'âshirah.
\end{abstract}

\begin{abstract}
Abstraksi
Riba merupakan suatu kelebihan atas modal. Hal tersebut meliputi semua jenis pinjaman uang dengan mengenakan tambahan yang banyak atau sedikit. Mayoritas umat Islam menyatakan bahwa bunga bank sama halnya dengan riba, sehingga bunga tersebut menjadi haram. Namun demikian, Muhammad Syahrûr mengatakan bahwa bunga bank itu bukan bagian dari riba, selama hal tersebut belum mencapai $100 \%$ dari modal yang ditanam. Metodologi yang digunakan oleh Syahrûr berbeda dengan apa yang digunakan oleh mayoritas ulama. la mengembangkan metodologinya sendiri dalam membuat suatu hukum. Salah satu teorinya adalah teori limit. Istilah limit (hudûd) yang digunakannya mengacu pada pengertian batas-batas ketentuan Allah yang tidak boleh dilanggar, tetapi di dalamnya terdapat wilayah ijtihad yang bersifat dinamis, fleksibel, dan elastis. Metode yang digunakan dalam malakah ini adalah deskriptif, sedangkan teknisnya adalah book survei atau studi kepustakaan, terutama terhadap buku yang dikarang oleh Muhammd Syahrûr, yaitu al-Kitâb wa al-Qur'ân: Qirâ'ah Mu'âshirah.
\end{abstract}

Kata Kunci:

Muhammad Syahrûr, Bunga Bank, Islam

\section{A. Pendahuluan}

Persoalan muamalah atau ekonomi Islam sampai sekarang masih menjadi persoalan menarik dan menjadi perdapatan para ulama adalah masalah bunga bank. Bunga bank dapat diartikan sebagai balas jasa yang diberikan oleh bank yang berdasarkan prinsip konvensional kepada nasabah yang mem- beli atau menjual produknya. ${ }^{1}$ Perdebatan para ulama mengenai bunga bank termasuk dalam kategori riba atau bukan? Apabila bunga bank termasuk riba, maka umat Islam tidak boleh bertransaksi atau bermuamalah dengan perbankan yang menerapkan sistem bunga, karena pada dasarnya riba disebut-

\footnotetext{
${ }^{1}$ Kasmir, Bank dan Lembaga Keuangan Lainnya (Jakarta: Raja Grafindo. 2002), hlm. 121.
} 
kan keharamannya dalam al-Quran. Sebagaimana dalam surat Âli Imrân ayat 130 berikut:

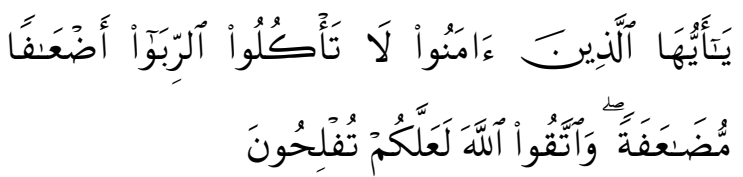

Hai orang-orang yang beriman, janganlah kamu memakan riba dengan berlipat ganda dan bertakwalah kamu kepada Allah supaya kamu mendapat keberuntungan.

Ayat di atas menjelaskan bahwa kata riba dari segi bahasa berarti kelebihan. Sehingga bila kita hanya berhenti kepada arti kelebihan, hal ini tidak akan banyak pengaruhnya dalam memahami pengertian atau esensi riba yang diharamkan dalam al-Quran, karena sebagaimana dikemukakan di atas, surat Âli Imrân ayat 130 yang menggunakan redaksi secara tegas terhadap mukmin agar tidak melakukan praktek riba secara adl'âfan mudlâ'afah. Surat ini memberikan pengertian bahwa dalam transaksi muamalah tidak boleh mengambil keuntungan secara berlipat ganda atau riba yang berlipat ganda. ${ }^{2}$

Istilah riba digunakan dalam al-Quran sebanyak dua puluh kali. Di dalam al-Quran istilah riba dapat dipahami dalam delapan macam arti, yaitu pertumbuhan, peningkatan, bertambah, meningkat, menjadi dasar, menjadi besar, besar, dan juga diartikan sebagai bukit kecil. Walaupun istilah riba tampak dalam beberapa makna, namun dapat diambil satu pengertian umum, yaitu meningkat, baik menyangkut kualitas maupun kuantitas. $^{3}$

Ada dua mendapat mengenai riba, yang pertama menyatakan bahwa riba itu semua kelebihan dari nilai pokok yang dipinjamkan. Sedangkan pendapat yang kedua adalah larangan riba itu terkait dengan unsur eksploitasi, yang secara ekonomis menimbulkan dampak yang sangat merugikan bagi masyarakat. Unsur eksploitasi ini kemungkinan

${ }^{2}$ Quraish Shihab, Membumikan al-Quran (Bandung: Mizan. 2003), hlm. 260.

${ }^{3}$ Abdullah Seed, Islamic Banking and Interest a Study of the Forhibition of Riba and its Contemporary Interpretation (Yogyakarta: Pustaka Pelajar. 2003.), hlm. 34 . terdapat dalam bunga bank, yang kemudian ada pendapat bahwa bunga bank itu haram. ${ }^{4}$

Pendapat lain tentang bunga bank adalah sebagaimana yang dinyatakan oleh $\mathrm{A}$. Hasan yang dikutip oleh Hendi Suhendi bahwa bunga bank seperti di negara ini bukan riba yang diharamkan, dengan argumentasi bahwa dalam bunga bank tidak berlipat ganda, seperti yang dinyatakan pada ayat tadi. ${ }^{5}$

Dalam hal ini Muhammad Syahrûr menjelaskan bahwa bunga bank itu tidak termasuk riba asalkan belum mencapai 100\% dari modal. Jadi, kaum muslim tidak perlu ragu untuk bertransaksi dengan bank yang menerapkan bunga, selama bunga belum mencapai $100 \%$ dari modal yang ditanam. ${ }^{6}$

Dalam pembaharuan hukum Islam, Syahrûr terkenal dengan teori batasnya. Syahrûr menegaskan bahwa teori limit (batas) merupakan salah satu pendekatan dalam berijtihâd, ini digunakan dalam mengkaji ayat-ayat muhkamat dalam al-Quran. Term limit yang digunakan Syahrûr mengacu pada pengertian "batas-batas ketentuan Allah yang tidak boleh dilanggar, tapi di dalamnya terdapat wilayah ijtihâd yang bersifat dinamis, fleksibel, dan elastis. ${ }^{7}$

Teori batas yang berhubungan dengan masalah muamalah serta berkaitan dengan riba adalah hadd al-a'lâ mujabban wa hadd aladnâ salîban (teori batas masimal dan teori batas minimum negatif). Artinya, bahwa batas maksimal negatif boleh dilewati dan diterapkan dalam masalah distribusi harta yang dapat dikategorikan dalam tiga bentuk, yaitu zakat, sadaqah, dan riba. Batas atas yang tidak boleh dilampaui adalah zakat sebagai batas negatif. Batas distributif di bawah zakat adalah sadaqah. Posisi ini selain memiliki batas atas dan juga batas tengah yang berada di tengah-tengah keduanya. Batas tengah ini disebut dengan titik nol pada persilangan kedua sumbu yang meng-

\footnotetext{
${ }^{4}$ Ibid. hlm. 27.

${ }^{5}$ Hendi Suhendi, Fiqh Muamalah (Jakarta: Rajawali Press. 2005), hlm. 282.

${ }^{6}$ Muhammad Syahrur, al-Kitâb wa al-Qur'ân: Qirâ'ah Mu'asirah (Damaskus: al-Halli li al-Tibâ'ah. 1990), hlm. 466.

${ }^{7}$ http//:www.islamlid.com
} 
implementasikan konsep qard al-hasan atau pinjaman dengan bunga nol persen. ${ }^{8}$

Singkatnya, bunga bank menurut Muhammad Syahrûr tidak termasuk riba, karena tidak bisa dikategorikan kepada adl'âfan mudhâ'afah.

\section{B. Landasan Berfikir Muhammad Syahrûr tentang Penetapan Batas Maksimal dan Minimal Bunga Bank \\ 1. Biografi Muhammad Syahrûr}

Muhammad Syahrûr dilahirkan di Damaskus, Syiria pada tanggal 11 April $1938 \mathrm{M}$. la adalah seorang guru besar di Universitas Syiria, Damskus. Bapaknya bernama Deyb ibnu Deyb Syahrûr dan ibunya adalah Shiddîqah binti Shâlih Filyun. Syahrûr menikah dengan 'Azîzah, dan dikaruniai lima orang anak, yaitu Tariq, al-Laits, Batsul, Masun, dan Rima. ${ }^{9}$

Seperti anak-anak pada umumnya Syahrûr memperoleh pendidikan di lembaga pendidikan 'Abdul al-Rahmân al-Kawâkibî, Damaskus. Setelah menamatkan pendidikan dasarnya, la meneruskan ke jenjang selanjutnya, semacam SLTP di lembaga pendidikan yang sama dan selesai pada tahun $1957 \mathrm{M}$. Pada tahun $1858 \mathrm{M}$, la pergi ke Uni Soviet untuk belajar ilmu teknik dengan beasiswa dari pemerintah. la belajar di Moskow sejak tahun 1959 M dan meraih diploma pada tahun 1964 M. Pada tahun 1965 M, Syahrûr kembali negaranya dan mengabdikan dirinya pada Universitas Syiria Damaskus. ${ }^{10}$

Pada tahun 1967 M, Syahrûr memperoleh kesempatan untuk melakukan penelitian di Imperial Collage London, Inggris. Namun la terpaksa harus kembali ke Syiria, karena pada saat itu terjadi "perang Juni" antara Syiria dan Israil yang mengakibatkan putusnya hubungan diplomatik Syiria dan Inggris." Selanjutnya la memutuskan untuk pergi ke Dublin, Irlandia guna melanjutkan studinya menempuh program magister dan doktora dalam bidang yang sama, dengan

${ }^{8}$ Ibid. hlm. 464.

9 lbid. hlm. 822.

${ }^{10}$ Ibid. hlm. 823 .

${ }^{11} \mathrm{M}$. Abied Shaleh, Unlawful Gain and Legitimate Profit in Islamic Law: Riba, gharar and (t.t: t.tp. 2001), hlm. 237. spesialisasi mekanika pertahanan dan fondasi sebagai utudan dari Universitas Damaskus di Ireland Nasional University. Di tahun 1969 M, Syahrûr menyelesaikan program magister dan tiga tahun kemudian, la menyelesaikan program doktoralnya. Pada tahun yang sama la diangkat menjadi dosen fakultas teknik Universitas Damaskus dan mengampu mata kuliah mekanika pertahanan dan geologi hingga sekarang. Selain kesibukannya sebagai dosen, sejak 1972 M, la bersama beberapa rekannya di fakultas membuka Biro konsultasi teknik. Pada tahun 1982-1983 M, la mendapat kesempatan menjadi tenaga ahli di Saudi Arabia pada alSaud Consult. ${ }^{12}$

Meskipun dasar pendidikannya adalah teknik, namun tidak berarti la sama sekali kosong dengan wacana kelslaman. la sangat tertarik untuk mengkaji al-Quran dan al-Sunnah secara lebih serius, dengan metode linguistiknya dan dibingkai dengan ilmu eksaknya. la menuangkan semua gagasannya ke dalam beberapa buku tentang pemikiran kelslaman. Gagasan kelslaman Syahrûr dituangkan dalam karya monumentalnya, yaitu al-Kitâb wa al-Qur'ân: Qira'âh Mu'âsirah. Buku Syahrûr ini menjadi best seller dan terjual dalam ribuan eksemplar. Buku ini telah dicetak beberapa kali. Cetakan pertamanya adalah pada tahun 1990 M dan pada 1992 M kembali di cetak. Eicklemen merekam bahwa pada tahun 1993 M buku ini telah terjual sebanyak 13.000 eks di Syiria, 3000 eks di Mesir, dan 10.000 eks di Saudi Arabia. ${ }^{13}$

Buku keduanya yang dipublikasikan adalah Dirâsah al-Islâmiyyah Mu'âsirah fi al-Dawlah wa al-Mujtama (1994 M). Buku ini merupakan pentar tentang jawaban atas kritikkritik yang diarahkan para pemikir muslim saat itu kepada buku pertamanya. Syahrûr mendapat banyak kritikan, dikarenakan pendekatan yang la gunakan sama sekali berbeda, yakni pendekatan eksakta ilmu teknik dan analisa matematika. Tetapi hal itu tidak membuat Syahrûr surut dalam mengembangkan wacana kelslaman. la kembali me-

\footnotetext{
${ }^{12}$ Muhammad Syahrir, al-Kitâb wa al-Qur'ân. hlm. 823.

${ }^{13}$ A. Khudari Shaleh, (2003), hlm. 295.
} 
nulis buku untuk yang ketiga yang la beri judul al-Islâm wa al-Imân: Manzûmah al-Qiyâm (1996 M). Ketiga buku inilah yang akan menggambarkan proyek pembaharuan Syahrûrdalam pemikiran Islam Kontemporer. Buku lain yang ditulis oleh Syahrûr adalah Masyru al-'amâl al-Islâm (1999 M) dan buku barunya adalah Nahwu Ushûl Jadîdatun li al-Fiqh al-Islâmî: Fiqh al-Mar'ah (2000 M), dalam buku ini la mencoba membaca kembali fiqh Islam klasik dengan mengangkat isu kesetaraan gender. ${ }^{14}$

Selain dipublikasikan dalam bentuk buku, Syahrûr juga sering menyumbangkan buah pikirannya lewat artikel-artikel dalam seminar atau media publikasi. ${ }^{15}$

\section{Pemikiran Muhammad Syahrûr tentang Bunga Bank}

Bank adalah salah satu lembaga bisnis, dan sistem bunga adalah salah satu mekanisme bank untuk mengelola peredaran dana di masyarakat. Anggota masyarakat yang memiliki dana dianjurkan untuk menititipkan dana yang tidak digunakan kepada bank untuk jangka waktu tertentu. Kemudian bank meminjamkan kembali dana tersebut kepada masyarakat lain yang membutuhkan untuk jangka waktu tertentu pula. ${ }^{16}$ Pada umumnya dalam ilmu ekonomi, bunga itu timbul dari sejumlah uang pokonya, yang lazim disebut dengan istilah kapital atau modal berupa uang. Dan bunga itu juga dapat disebut dengan istilah rent atau dikenal dengan interest. Menurut Goeghart, bunga atau rente itu adalah perbedaan nilai, tergantung pada perbedaan waktu yang berdasarkan atas perhitungan ekonomi. ${ }^{17}$

Interest dalam kamus ekonomi Sloan dan Zucher yang di kutip oleh Karnean A. Perwaatamadja adalah sejumlah uang yang

\footnotetext{
${ }^{14} \mathrm{M}$. Khairul Muqtafa, Membincang Figh al-Mar'ah ala Syahrur (Jurnal Tashwirul Afkar, edisi Islam Pribumi; Menolak Arabisme, Mencari Islam Indonesia, No. 14 tahun 2003), hlm. 197.

${ }^{15}$ Muhammad Syahrir, al-Kitâb wa al-Qur'ân. hlm. 824.

${ }^{16}$ Munawar Syadzali, ljtihad Kemanusiaan. hlm. 14

${ }^{17}$ Syahirin Harahap, Bunga Uang dan Riba dalam Hukum Islam (Jakarta: Pustaka al-Husna. 1993), hlm. 1819.
}

dibayar atau penggunaan modal. jumlah tersebut misalnya dinyatakan dengan satu tingkat atau presentasi modal yang bersangkut paut dengan hak itu dinamakan suku bunga modal. ${ }^{18}$

Sistem bunga dalam bank konvensional atau bagi hasil dalam bank syariah sianggap penting demi keberhasilan pengoprasian sistem ekonomi yang ada bagi masyarakat. Tetapi Islam pempertimbangkan bunga itu sebagai kejahatan yang menyebarkan kesengsaraan dalam kehidupan. ${ }^{19}$

Dalam literatur ulama fiqh klasik tidak dijumpai pembahasan yang mengaitkan antara riba dan bunga perbankan. Sebab lembaga perbankan seperti yang berkembang sekarang ini tidak dijumpai dalam zaman mereka. Bahasan mengnai apakah bunga itu identik dengan riba baru di temui pada literatur fiqh kontemporer.

Al-Quran mengakui bahwa meminum minuman keras itu bukan tidak ada manfaatnya sama sekali, tetapi Islam mengharamkannya karena akibat buruk yang terkandung di dalamnya lebih banyak dibandingkan dengan manfaatnya. Kita mengakui bahwa sistem bunnga pada berbankan itu tidak selalu baik, dan bahkan dapat mencelakakan nasabah yang meminjam uang dari bank. Akan tetapi, jumlah nasabah yang tertolong karenanya jauh lebih banyak dari pada yang dirugikan. Maka jika dianalogikan dengan hukum minum minuman keras, sistem bunga dalam berbankan konvensional itu tidak haram. ${ }^{20}$ Namun ada pula yang mengidentikan bunga bank sama dengan riba, dan hukumnya pun haram.

Secara etimologi, kata riba memiliki makna "al-Ziyâdah" yang berarti tambahan, karena salah satu perbuatan riba adalah meminta tambahan dari sesuatu yang dihutangkan. ${ }^{21}$ Pengertian yang sama terdapat pada

\footnotetext{
${ }^{18}$ Karnean A. Perwaatmadja, Bank Syariah Teori, Praktik, dan Peranannya (Jakarta: Celestial Publishing. 2007), hlm.03.

${ }^{19}$ Afzalur Rahman, Doktrin Ekonomi Islam (Yogyakarta: Dana Bakhti Prima. 2002), Jilid III, hlm. 76

${ }^{20}$ Munawir Syazali, ljtihad Kemanusiaan (Jakarta: Paramadina. t.th), hlm. 65.

${ }^{21}$ Hendi Suhendi, Fiqih Muamalah. hlm. 57.
} 
kamus al-Munawwir bahwa riba berarti tambahan, kelebihan. ${ }^{22}$

Adapun secara istilah, pengertian riba terdapat beberapa perbedaan, sesuai dengan pengertian masing-masing menurut sebab penetapan haramnya. ${ }^{23}$ Menurut Abdurrahmân al-Juzayri, riba adalah nilai tambahan pada salah satu dari dua barang yang sejenis, ditukar tanpa ada imbalan terhadap tambahan tersebut. ${ }^{24}$ Sedangkan menurut Sayyid Sâbiq, riba adalah tambahan atas modal, baik penambahan itu sedikit ataupun banyak. ${ }^{25}$

Umat Islam dilarang mengambil riba apapun jenisnya. Larangan supaya umat Islam tidak melibatkan diri dengan riba bersumber dari berbagai surat dalam al-Quran dan hadits rasulullah saw.. Menurut Sayyid Quthb dan Abdul al-A'lâ al-Mawdûdi yang dikutip oleh Muhammad Syafi'i Antonio bahwa larangan riba yang terdapat dalam riba yang terdapat dalam al-Quran tidak sekaligus melainkan secara bertahap. ${ }^{26}$

Tahap pertama, adalah surat al-Rum ayat 39:

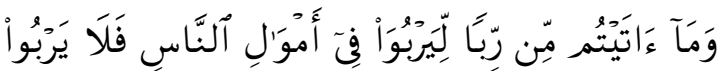

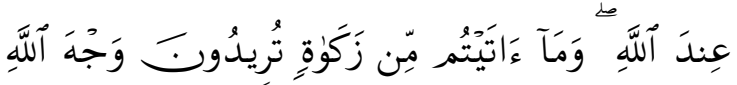

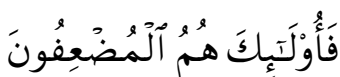

Dan sesuatu riba (tambahan) yang kamu berikan agar dia bertambah pada harta manusia, Maka riba itu tidak menambah pada sisi Allah. dan apa yang kamu berikan berupa zakat yang kamu maksudkan untuk mencapai keridhaan Allah, Maka (yang berbuat demikian) Itulah orang-orang yang melipat gandakan (pahalanya).

\footnotetext{
${ }^{22}$ Ahmad Warson Munawwir, Kamus al-Munawwir (Yogyakarta: Pustaka Progresif. 1997), hlm. 469.

${ }^{23}$ Abû Surấi Abdul Hâdi, al-Riba wa al-Qurûd (Surabaya: al-Ikhlas. 1993), hlm. 24.

${ }^{24}$ Abdurrahmân al-Juzayri, al-Fiqh 'alâ Madzâhib alarba'ah (Beirut: Dâr al-Fikr. 1972), vol. II, hlm. 196.

${ }^{25}$ Sayyid Sâbiq, Fiqh Sunnah (Bandung: PT alMa'arif. 1987), Vol. 12, hlm. 125.

${ }^{26}$ Syafi'i Antonio, Bank Syariah: dari Teori ke Praktik (Jakarta: Gema Insani. 2001), hlm. 48.
}

Tahap Kedua, riba digambarkan sebagai suatu yang buruk. Adalah surat al-Nisâ ayat 160 dan 161:

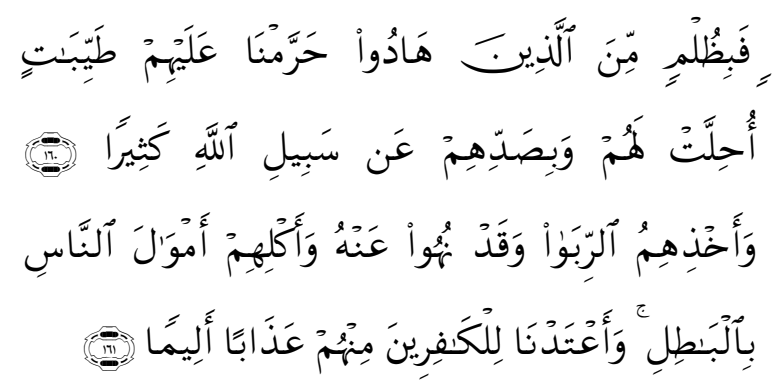

Maka disebabkan kezaliman orang-orang Yahudi, kami haramkan atas (memakan makanan) yang baik-baik (yang dahulunya) dihalalkan bagi mereka, dan Karena mereka banyak menghalangi (manusia) dari jalan Allah. (160) Dan disebabkan mereka memakan riba, padahal Sesungguhnya mereka Telah dilarang daripadanya, dan Karena mereka memakan harta benda orang dengan jalan yang batil. kami Telah menyediakan untuk orangorang yang kafir di antara mereka itu siksa yang pedih. (161)

Tahap ketiga, riba dikaitkan dengan sesuatu tambahan yang berlipat ganda, yaitu pada surat Âli-Imrân ayat 130:

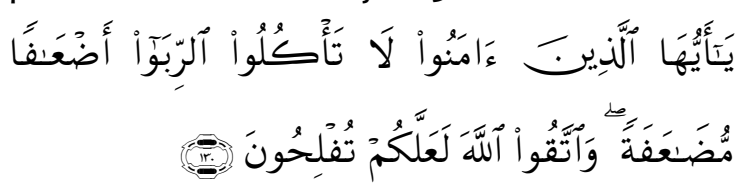

Hai orang-orang yang beriman, janganlah kamu memakan riba dengan berlipat ganda dan bertakwalah kamu kepada Allah supaya kamu mendapat keberuntungan.

Tahap terakhir, Allah SWT dengan jelas dan tegas mengharamkan apupun jenis riba, yaitu pada surat al-Baqarah ayat 278 dan 279:

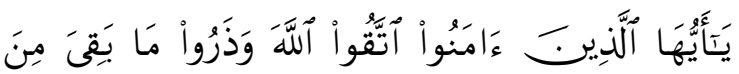

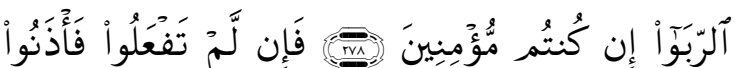

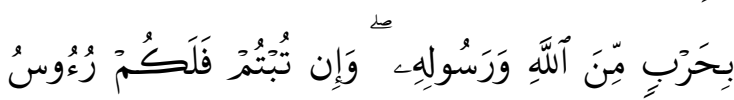

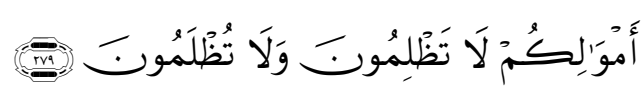
Hai orang-orang yang beriman, bertakwalah kepada Allah dan tinggalkan sisa riba (yang belum dipungut) jika kamu orang-orang yang 
beriman. (278) Maka jika kamu tidak mengerjakan (meninggalkan sisa riba), Maka Ketahuilah, bahwa Allah dan rasul-Nya akan memerangimu. dan jika kamu bertaubat (dari pengambilan riba), Maka bagimu pokok hartamu; kamu tidak menganiaya dan tidak (pula) dianiaya. (279)

Di luar pembahasan riba yang disampaikan oleh beberapa ulama di atas, sekarang kita bembahas pemikiran Muhammad Syahrûr mengenai bunga bank itu sendiri, untuk memperjelas tentang pemikiran beliau, secara umum gagasan-gagasan Syahrûr terbagi ke dalam tiga fase.

Pertama, tahun 1970-1980 M. Fase ini dimulai saat la studi di Universitas al-Qayûmiyyah al-Irlandiyyah di Dublin, Irlandia. Sebelum la memperoleh gelar megister dan doktornya dalam bidang mekanika tanah. la merasakan bahwa kajian kelslamannya tidak menghasilkan sesuatu yang bermakna terutama saat la mengkaji al-Dzikr (al-Quran), baik itu metodologi, istilah pokok, maupun tentang risalah dan kenabian. la melihat bahwa kajian kelslaman telah terjebak ke dalam kondisi taqlid dan pembahsannya hanya itu-itu saja mengekor pada pemikiran trasisi klasik. Hal ini telah menjadi ideologi yang membunuh pembahasan yang bersifat ilmiah. Dengan demikian, la ingin menghadirkan produk pemikiran masa lalu kepada masa kini dengan seluruh problemnya. ${ }^{27}$

Fase kedua, tahun 1980-1986. Pada tahun 1980 Syahrir bertemu dengan Ja'far Dak al-Bab, seorang teman yang lulus doktornya di Universitas Moskow dalam ilmu bahasa (al-Lisaniyyat) tahun 1973. Dari beliau Syahrir belajar ilmu linguistik. Jafar mengenalkan Syahrûr akan pemikiran-pemikiran tokoh besar, seperti al-Farabî, Abu Ali al-Farisî, Ibnu Jinnî, dan Abdul Qohar al-Jurzanî. Dari pemikiran mereka Syahrûr dapat mengerti tentang pemahaman kebahasaan yang lebih komprehensif. Selanjutnya la mulai untuk mengkaji ulang tema-tema penelitian yang sudah dilakukan sebelumnya. Seperti pengertian terminologis dari al-Kitâb, al-Qur'ân, 46.
al-Furqân, al-Dzikr, Umm al-Kitâb, al-Lawh alMahfudz, al-Hadîts, dan Ahsân al-Hadîts. la mengkaji ulang dengan perspektif baru seperti al-Inzâl wa al-Tânzil, dan al-Ja'far, yang la kaji sampai bulan Mei 1982 M. $^{28}$

Fase Ketiga, tahun 1986-1990 M. Fase ini adalah upaya sistematisasi dari berbagai pemikirannya, dimana la menyusun kembali dan memilah tema dari hasil peneltian bersama Ja'far dalam bentuk buku yang kemudian diterbitkan pada tahun 1990 M. ${ }^{29}$

Metode yang digunakan Syahrûr dalam merekontruksi pemikiran kelslaman adalah metode kebahasaan..$^{30}$ Epistimologi yang berangkat dari tekstualitas nash, la mengkaji kembali istilah-istilah kelslaman. Syahrûr melakukan reinterpretasi ulang terhadap tematema dalam al-Quran dan al-Sunnah yang la jadikan sebagai landasan hukum. la adalah pemikir yang memulai kajian kelslamannya dengan epistimologi bayani-meminjam bahasa Abed al-Jabirî.

Dasar hukum Syahrûr adalah al-Quran, dan al-Sunnah, la tidak menggunakan ljma' dan Qiyâsh. Pemahaman terhadap keduanya pun berbeda dengan pemahaman ulama pada umumnya.

\section{a. Al-Quran}

Dengan berangkat dari kajian kebahasaan, Syahrûr mengkaji kembaliterm yang berkatan dengan al-Quran. Bagi Syahrûr, term al-Qur'ân, al-Furqân, al-Dzikr, al-Kitâb, dan istilah lainnya memiliki makna sendirisendiri. Mushaf Utsmani yang selama ini populer dengan al-Quran, oleh Syahrûr disebut dengan al-Kitâb. Term al-Kitâb berasal kata dari kataba, yang berarti pengumpulan sesuatu untuk memperoleh manfaat atau untuk membentuk sebuah tema yang sempurna. ${ }^{31}$ Dalam hal ini Syahrûr berusaha melakukan dekontruksi sekalibus rekontruksi terhadap berbagai konsep, teori dan paradigma yang telah mapan menjadi mainstrim pema-

\footnotetext{
${ }^{28}$ Ibid. hlm. 47.

${ }^{29}$ lbid. hlm. 48.

${ }^{30} \mathrm{Ibid}$. hlm. 44.

${ }^{31} \mathrm{lbid}$. hlm. 66.
} 
haman, pemikiran, bahkan keyakinan mayoritas muslim. ${ }^{32}$

\section{b. Al-Sunnah}

Menurut Syahrûr "sunnah" berasal dari kata sanna yang dalam bahasa Arab berarti "mudah dan mengalir dengan lancar", seperti perkataan mâ'un masnûn, yang berarti air yang mengalir dengan mudah. Syahrûr membendakan antara sunnah dan hadits. Menurutnya sunnah adalah meode dalam menetapkan hukum-hukun dengan cara yang mudah tanpa keluar dari limit-limit yang telah ditentukan oleh Allah SWT, baik dalam masalah-masalah yang limitnya dalam al-Quran maupun membuat limit-limit baru yang bersifat temporer dalam berbagai persoalan, dengan memperhatikan realitas dan kondisi sosial kultural yang akan dijadikan tempat penerapan hukum. Sedangkan hadits adalah ijtihad nabi dalam pembacaan terhadap kitab suci. ${ }^{33}$

\section{c. Ijma' dan Qiyash}

Menurut Syahrûr ijma' yang benar adalah kesapakatan mayoritas masyarakat mengenai suatu masalah yang mereka hadapi, dan kesepakatan tersebut harus didapat dengan jalan demokratis dan tidak keluar dari batas-batas ketetapan syar'i. Syahrûr menilai definisi yang diberikan ulama terdahulu adalah keliru, karena kesepakatan yang mereka ambil adalah untuk menyelesaikan masalah pada masanya, sementara realitas sekarang tidak ada hubungannya dengan peristiwa dahulu. Sedangkan yang dimaksud dengan qiyash adalah proses penganalogian sesuatu yang ada sekarang dengan sesuatu yang ada sekarang, dengan syarat masih berada pada batasan syar'i. Dengan kata lain la memengang scientific analogy, karena la menganalogikan secara induktif hal-hal dan ketentuan yang di dukung secara empiris. ${ }^{34}$

${ }^{32}$ Sahiron Syamsudin, Mempertimbangkan Metode Tafsir Muhammd Syahrur (Yogyakarta: Forstudia Islmika. 2004.), hlm. 87.

${ }^{33}$ Muhammad Syahrur, al-Kitab wa al-Qur'an.hlm. 546-549.

${ }^{34}$ lbid. hlm. 581-582.

\section{Batas Maksimal dan Minimal Bunga Bank Menurut Muhammad Syahrûr}

Syahrûr mengatakan bahwa pemaham kelslaman selama ini ada beberapa yang harus dipahami, yaitu hudûd, al-Istiqâmah, dan al-hanâfiyyah. Hudud merupakan batasan-batasan hukum yang ditentukan oleh Allah swt., baik maksimal maupun minimal, dan versi diantara keduanya. ${ }^{35}$

Sedangkan al-Istiqâmah, dan al-hanâfiyyah berasal dari dimensi universalitas Islam. Term al-hanîf bersal dari kata hanafa yang berarti bengkok. Adapun term Istiqâmah, adalah mustaq dari qaym yang memiliki arti beberapa kumpulan laki-laki, berdiri tegak (alIntishâb) dan kuat (al-'azm). Dan lafal alIntishâb muncul dari kata al-mustaqîm dan alIstiqâmah, yakni akronim dari melengkung. Sedangkan dari kata al-'azl muncul kata al-Dîn al-Qoyyim. ${ }^{36}$

Syahrûr mengumpamakan al-hanâfiyyah sebagai kondisi sosial yang meliputi nashnash al-Quran dalam perjalanan sejarahnya, sejak diturunkan sampai sekarang. Sedangkan al-Istiqâmah sebagai batasan yang telah ditentukan oleh Allah dalam nash al-Quran. Disamping dengan analisa paradigma sintagmatis ini, la pun merumuskan analisanya dengan analisis matematik. ${ }^{37}$

Dari sinilah la memperkenalkan teori batasnya. Asumsi dasarnya adalah bahwa Allah menetapkan batasan-batasn hukum maksimum dan minumum, dan manusia senantiasa bergerak dari dua batasan ini. ${ }^{38}$

a. Batas Minimum

Posisi batas minimal merupakan batas paling rendah yang ditentukan oleh Allah, manusia tidak boleh melakukan ijtihâd mengurangi batas tersebut. Tetapi memungkinkan untuk menambahnya. Sebagai contoh tentang wanita yang haram untuk dinikahi. Menurutnya, itu tidak boleh di kurangi, tetapi mungkin untuk ditambah. Misalnya hasil penelitiain kedokteran, menyebutkan bahwa menikahi anak perempuan yang diharamkan

\footnotetext{
${ }^{35}$ Ibid. hlm. 453.

${ }^{36} \mathrm{lbid}$. hlm. 448.

${ }^{37}$ M. In'am Esha,Muhammad Syahrur: Teori Batas (Yogyakarta: Jendela. 2003.), hlm. 308.

${ }^{38}$ Muhammad Syahrur, al-Kitâb al-Qur'ân. hlm. 453-466.
} 
yaitu pada anak paman dan bibi dapat berakibat buruk bagi keturunan, maka hal tersebut dapat ditambah walaupun dalam Islam tidak ada ketentuan seperti itu. ${ }^{39}$

\section{b. Batas Maksimum}

Adalah batas paling atas yang telah ditentukan Allah dalam al-Quran. Ruang gerak ijtihad bergerak turun, artinya bahwa ketentuan tersebut merupakan batasan maksimal yang tidak boleh dilampaui tetapi boleh atau memungkinkan untuk dikurangi. Misalnya had pencurian, yaitu potong tangan. ${ }^{40}$

\section{c. Batas Minimum dan Maksimum Saling} Berhubungan

Posisi batas ini merupakan gabungan antara batas minimal dan maksimal, artinya bahwa batas tersebut telah ditetapkan oleh Allah. Wilayah ijtihadnya adalah naik-turun diantara keduanya. Contohnya dalam masalah bagian waris laki-laki dan wanita dan masalah poligami dalam al-Quran surat al-Nisâ ayat $3 .{ }^{41}$

d. Batas Minimum dan Maksimum Sekaligus Tapi dalam Satu Titik Koordinat

Dalam posisi batas maksimumnya juga terjadi batas minimum, dan ijihad tidak mungkin mengambil hukuman yang lebih berat dan ringan. Contohnya dalam kasus perzinaan, hukumannya adalah 100 kali cambukan, dan itu merupakan batas maksimum dan batas minimumnya.

e. Batas Maksimum dengan Satu yang Cenderung Mendekati Garis Lurus Tapi Tidak Ada Persentuhan

Posisi ini diterapkan dalam batasan hubungan antara pria dan wanita. Dalam batas paing atas telah ditentukan dalam al-Quran, namun karena tidak ada persentuhan dengan batas maksimum maka hukuman belum dapat ditetapkan, yaitu hukuman zinâ. Menurutnya, hal tersebut telah dapat dipahami sebagai hubungan antara pria dan wanita, namun jika tidak adanya persentu-

\footnotetext{
${ }^{39} \mathrm{lbid} . \mathrm{hlm} .454$.

${ }^{40}$ Ibid. hlm. 455.

${ }^{41}$ Lebih lanjutnya lihat Ibid. hlm. 448.
}

han secara maksimal, yaitu bertemunya kelamin, dan adanya keterangan dari empat orang saksi. Apabila tidak ada empat orang saksi, maka hal tersebut disebut fakhîsyah, dengan demikian pertanggungjawabannya bersifat individual, bisa melalui istighfar dan tawbat.

f. Batas Maksimal Positif Tidak Boleh Dilewati, Batas Minimal Boleh Dilewati

Posisi ini diterapkan dalam masalah distribusi harta, yang dapat dikategorikan dalam bentuk zakât, shadaqah, dan riba. Batas atas yang tidak boleh dilampaui adalah riba, sementara batas minimal atau bawah yang boleh dilewati adalah zakat sebagi batas negatif, batas distributif di bawah zakat adalah sadaqah. Posisi ini selain memiliki batas atas dan bawah juga memiliki batas tengah yang tepat berada di tengah-tengan keduanya. Batas tengah ini disebutkan dengan titik nol pada persilangan kedua sumbu yang mengimplementasikan konsep Qord al-Hasan atau pinjaman denga bunga $0 \%$. Yang dinamakan riba pada bunga bank menurut Syahrûr adalah ketika bunga pinjaman melebihi $100 \%$ dari modal pinjaman dengan penafsiran adl'âfan mudhâ'afah. ${ }^{42}$

Dalam teori ini Syahrûr memperkenalkan kajian bunga secara baik dan terperinci dengan mengutip beberapa ayat al-Quran yang berhubungan dengan masalah riba. Syahrûr juga menjelaskan bahwa arti riba dalam bahasa arab adalah "pertumbuhan dan perkembangan" dari kekayaan. Syahrûr berpendapat bahwa larangan atas bunga adalah bukan ketentuan dari Islam. Dalam mendukung pendapatnya la pun menyebutkan bahwa 'Umar bin Khattab suatu ketika dilaporkan menginginkan nabi agar menjelaskan secara eksplisit syarat-syarat stastus hukum bunga. ${ }^{43}$

Munurutnya, umat Islam tidak perlu khawatir dan ragu ketika harus bertransaksi dalam dunia perbankan yang menggunakan sistem bunga/konvensional. Asalkan bunga yang diperoleh belum mencapai 100\% dari modal awal. Syahrûr menegaskan bahwa

\footnotetext{
${ }^{42}$ Ibid. hlm. 464

${ }^{43}$ Ibid. hlm. 468.
} 
bentuk riba yang dilarang adalah ketika bunga itu mencapai $100 \%$. Jadi, selama bunga kurang dari jumlah itu, masih dalam kategori yang dibolehkan, dalam arti tambahan itu belum melanggar batas ketentuan Allah.

Menurut Syahrûr , kata adl'âfan mudhâ'afah merupakan batas atas (maksimal) yang tidak boleh dilampaui, yakni ketika bunga $100 \%$ dari uang pokok yang pinjam. Disinilah ijtihâd sangat diperlukan untuk menentukan presentase yang tepat agar roda perekonomian dapat berputas secara normal. Tentunya seorang ahli hukum islam harus bekerja sama dengan ahli ekonomi, khususnya berbankan.

\section{Implikasi Pendapat Muhammad Syah- rûr tentang Bunga Bank terhadap Sis- tem Perbankan di Indonesia}

1. Implikasi terhadap Bank Konvensional

Kata bank berasal dari kata banque dalam bahas Prancis dan banco dalam bahasa Italy, yang memiliki pengertian peti, lemari, atau bangku. Kata peti atau lemari menyiratkan fungsi sebagai tempat penyimpanan benda-benda berharga, seperti emas, berlian, dan lainnya. Dalam al-Quran, istilah bank tidak disebutkan secara eksplisit. Tetapi jika dimaksud adalah sesuatu yang memiliki unsur-unsur, seperti struktur, manejemen, fungsi, hak, dan kewajiban, maka itu semua dijelaskan dalam al-Quran, seperti zakât, shadaqah, rampasan perang, jual beli, utang dagang, harta, dan sebaginya yang memiliki peran tertentu dalam ekonomi Islam. ${ }^{44}$

Dalam hal ini, bank konvensional memiliki arti sebagai institusi bank yang dalam operasionalnya menerapkan metode bunga. Bunga merupakan produk zaman dahulu, yang kemudian menjadi kebiasaan untuk diterapkan. Bank konvensinal menerapkan bunga pada pada giro, tabungan, deposito, fee based, dan lain sebagainya. Singkatnya, bank konvensional adalah institusi keuangan yang menjalankan usahanya melalui sistem bunga. ${ }^{45}$

\footnotetext{
${ }^{44}$ Heri Sudarsono, Bank dan Lembaga Keuangan Syariah (Yogyakarta: Ekonisia. 2004), hlm. 27.

${ }^{45}$ Edi Wibowo, dkk,Mengapa Memilih Bank Syariah (Bogor: Ghalia Indonesia. 2005), hlm. 21.
}

Implikasi pendapat Syahrûr tentang bunga bank yang menyatakan bahwa itu bukan termasuk riba dapat meningkatkan operasional yang di bangun oleh berbankan konvensional.

Dari aspek nasabah, mereka akan semakin mempercayai pihak perbakan untuk mendapatkan keuntungan dari dana yang disimpannya. Karena pada dasarnya, nasabah menyimpan dananya di bank ia ingin dananya tersebut memiliki nilai tambah, atau dengan kata lain bunga. ${ }^{46}$

\section{Implikasi terhadap Bank Syariah}

Bank syariah adalah lembaga keuangan yang usaha pokonya adalah memberikan pembiayaan dan jasa-jasa lain dalam lalu lintas pembayaran serta peredaran uang yang pengoprasiannya berdasarkan dengan prinsip-prinsip syariah. ${ }^{47}$

Menurut Masyfuq Zuhdi, ada beberapa alasan Ulama dan Cendikiawan muslim menganjurkan berdirinya bank syariah adalah sebagi berikut:

a. Umat Islam telah berda dalam keadaan yang darurat, sebab dalam kehidupan modern sekarang, umat Islam hampir tidak bisa menghindarkan diri dari bermuamalah dengan bank yang menggunakan sistem bunga dalam segala aspek kehidupan, termasuk agama dan ibadahnya;

b. Untuk menyelelamatkan umat Islam dari praktek bungn yang mengandung unsur eksploitasi dari orang kaya terhadap orang miskin atau orang yang kuat ekonominya terhadap orang yang lemah ekonominya;

c. Untuk menyelamatkan ketergantungan umat Islam berada di bawah kekuasaan bank, sehingga umat Islam tidak bisa menerapkan ajaran agamanya dalam kehidupan pribadi dan masyarakat, terutama dalam kegiatan bisnis dan ekonomi;

\footnotetext{
${ }^{46}$ Marulak Pardede. Perspektif Perlindungan Hukum Simpanan Dana Nasabah Pada Bank.Jurnal Hukum Bisnis. Volume 11 No. 7. 2000., hlm. 57.

${ }^{47}$ Warkum Sumitro, Asas-asas Perbankan Islam Dan Lembaga-lembaga Terkait (Jakarta: Rajawali Press. 2004.), hlm. 05.
} 
d. Untuk menghindari perselisihan dikalangan para ulama. Perselisihan tersebut ialah mengenai haram atau tidaknya bunga bank; ${ }^{48}$

Dengan demikian, Implikasi pendapat Muhammad Syahrûr mengenai kebolehannya bunga bank adalah akan menjadi salah satu faktor penghambat untuk peningkatan dan pembangunan bank syariah itu sendiri, karena para nasabah muslim yang enjoy dengan bank konvensionalnya akan semakin kuat bahwa apa yang ia lakukan tidak bertentangan dengan kaidah agama. Disamping itu, para calon nasabah bank syariah akan pikirpikir kembali untuk menjadi bagian nasabah bank syariah, karena minimnya informasi dan sedikitnya jaringan yang dimiliki bank syariah dibandingkan dengan bank konvensional.

Namun demikian, pada prinsipnya pemikiran Muhammad Syahrûr ini tidak akan memberikan dampak yang sangat besar, karena Majelis Ulama, khususnya yang ada di Indonesia telah memberikan fatwa bahwa bunga itu identik dengan riba, sehingga hukumnya haram, ditambah dengan fatwa-fatwa yang telah disampaikan oleh para ulama besar lainnya, seperti Yusuf al-Qardlâwi, Umar Chapra, dan lain sebagainya.

\section{Analisis Pemikiran Muhammad Syahrûr tentang Bunga Bank}

Pendapat dibolehkannya bunga bank menurut Syahrûr didasarkan pemahamannya dalam menafsirakan lafadz adl'âfan mudlâ'afah pada surat Âli-Imrân ayat ke 130 berikut:

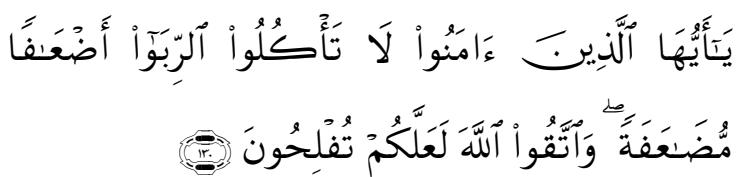

Hai orang-orang yang beriman, janganlah kamu memakan riba dengan berlipat ganda dan bertakwalah kamu kepada Allah supaya kamu mendapat keberuntungan.

Menurutnya, ayat tersebut merupak batasan maksimal yang ditetapkan oleh Allah

\footnotetext{
${ }^{48}$ Masyfuq Zuhdi, Masâ'il Fiqhiyyah (Jakarta: Toko Gunung Agung. 1997.), hlm. 113.
}

SWT, sehingga apabila bunga tersebut tidak melebihi 100\%, maka bunga bank boleh.

Kelemahan pendapatnya ini adalah bahwa Syahrûr tidak membagi konsep bunga bank ke dalam bunga konsumtif dan bunga produktif. Secara metodologi argumen Syahrûr ini pun telah dibantah oleh para ulama yang mengharamkan riba seperti yang telah penulis sebutkan di atas, karena ulama yang mengharamkan riba secara mutlak tidak mendasarkan metode mahfum mukhâlafah dengan mahfum 'adâd. Karena lafadz adl'âfan mudhâ'afah ini telah dijelaskan dalam hadits rasulullah.

Dalam hal ini Rasulullah saw. melarang menjual perak dengan perak, kecuali sama beratnya, dan emas dengan emas kecuali sama beratnya, dan kita boleh menjual emas dengan perak sesuai dengan kehendak kita.

Hadits Rasulullah di atas sebenarnya menerangkan bahwa yang dimaksud dengan lafadz adl-'âfan mudhâ'afah yang menjadi dasar bagi keharaman riba, adalah segala kelebihan dari modal dasar, baik hutang maupun jual beli yang berkelipatan 100\% ataupun tidak, dan kelebihan itu sifatnya merugikan bagi penghutan atu pembeli.

Kriteria berlipat ganda harus dipahami sabagai hâl atau sifat dari riba dan sama sekali bukan syarat. Apabila kita menjadikan lafadz tersebut menjadi syarat, maka jika terjadi penglipatan menjadi riba, dan jika tidak maka bukan riba. Menurut 'Abdullah Darz yang dikutip oleh Syafi'i Antonio menegaskan bahwa terdapat kerapuhan asumsi jika lafazh tersebut dijadikan syarat. la menjelaskan secara linguistik dha'fun artinya "Kelipatan" atau sesuatu yang berlipat dua kali lebih besar dari semula. Sedangkan adl'af adalah bentuk jama dari dha'fun, berarti jumlah lipatannya lebih dari tiga, atau $2 \times 3$. Adapun mudlâ'afah dalam kalimat tersebut adalah penguat ( $t a^{\prime} k i ̂ d$ ). Dengan demikian, menurutnya kalau berlipat ganda dijadikan syarat, maka sesuai dengan konsekuansi bahasa minimum 6 kali atau bunga $600 \%$. Secara operasional dan nalar sehat angka itu mustahil terjadi dalam proses perbankan maupun simpanan. ${ }^{49}$

\footnotetext{
${ }^{49}$ Syafi'i Antonio, Bank Syariah.hlm. 56.
} 


\section{Penutup}

Bunga bank menurut Muhammad Syahrûr adalah halal atau boleh. Kebolehan ini didasarkan karena la menggunkan perspektif berbeda dalam memahami ayat yang menerangkan tentang riba, terutama terhadap penafsiran kandungan makna di dalam surat Ali 'Imrân ayat 130. Dalam meahami ayat tersebut, la menggunakan metodologi sendiri dalam memahami ayat tersebut, yaitu dengan teori limitnya. Menurutnya, bunga bank tidak termasuk riba sebelum bunganya tersebut mencapai $100 \%$, sebab larangan atas bunga merupakan ketentuan yang tidak ada dalam Islam. Pendapat Syahrûr ini menimbulkan kontripersi dikalangan ulama, salah satunya ialah Abdullah Darz, la menyatakan bahwa pendapat yang mengatakan jika bunga tidak melampaui $100 \%$ tidak termasuk riba ini, apabila melalui pendekatan linguistik, maka tidak masuk nalar manusia. Sehingga pendapat yang dikemukakan Syahrûr harus dikaji ulang.

Jika dilihat dari sistem perbankan Islam secara global, sedikit banyaknya pemikiran Syahrûr ini akan memberikan dampak negatif dalam perkembangan perbankan syariah dan berpengaruh positif bagi perkembangan dan keberlangsungan perbankan konvensional, karena nasabanya yang muslim akan merasa tidak bersalah jika berhubungan dengan bank konvensional. Namun sebaliknya, perbankan syariah akan memiliki kesulitan untuk berkembang.

Namun demikian, pada prinsipnya pemikiran Muhammad Syahrûr ini tidak akan memberikan dampak yang sangat besar, karena Majelis Ulama, khususnya yang ada di Indonesia telah memberikan fatwa bahwa bunga itu identik dengan riba, sehingga hukumnya haram, ditambah dengan fatwafatwa yang telah disampaikan oleh para ulama besar lainnya, seperti Yusuf al-Qardlâwi, Umar Chapra, dan lain sebagainya.

\section{Daftar Pustaka}

Antonio, Syafi'i. 2001. Bank Syariah: dari Teori ke Praktik. Jakarta: Gema Insani.
Esha, M. In'am. 2003. Muhammad Syahrûr: Teori Batas. Yogyakarta: Jendela.

Hadi, Abu Surâ‘i Abdul. 1993. al-Ribâ wa alQurûd. Surabaya: al-Ikhlas.

Harahap, Syahirin. 1993. Bunga Uang dan Riba dalam Hukum Islam. Jakarta: Pustaka alHusna. http//:www.islamlid.com.

Juzayri, Abdurrahmân, al-. 1972. al-Fiqh 'alâ Madzâhib al-arba'ah. Beirut: Dâr al-Fikr.

Kasmir. 2002. Bank dan Lembaga Keuangan Lainnya. Jakarta: Raja Grafindo.

Munawwir, Ahmad Warson. 1997. Kamus alMunawwir. Yogyakarta: Pustaka Progresif.

Muqatafa, M. Khairul. Membincang Fiqh alMar'ah ala Syahrûr (Jurnal Tashwirul Afkar, edisi Islam Pribumi; Menolak Arabisme, Mencari Islam Indonesia, No. 14 tahun 2003.

Pardede. Marulak. Perspektif Perlindungan Hukum Simpanan Dana Nasabah Pada Bank. Jurnal Hukum Bisnis. Volume 11 No. 7. 2000.

Perwaatmadja, Karnean A. 2007. Bank Syari'ah Teori, Praktik, dan Peranannya. Jakarta: Celestial Publishing.

Rahman, Afzalur. 2002. Doktrin Ekonomi Islam. Yogyakarta: Dana Bakhti Prima

Seed, Abdullah. 2003 Islamic Banking and Interest a Study of the Forhibition of Riba and its Contemporary Interpretation. Yogyakarta: Pustaka Pelajar.

Shaleh, M. Abied. 2001. Unlawful Gain and Legitimate Profit in Islamic Law: Riba and gharar. t.t: t.tp.

Shihab, Quraish. 2003. Membumikan alQuran. Bandung: Mizan.

Sudarsono, Heri. 2004. Bank dan Lembaga Keuangan Syariah. Yogyakarta: Ekonisia.

Suhendi, Hendi. 2005. Figh Muamalah. Jakarta: Rajawali Press.

Sumitro, Warkum. 2004. Asas-asas Perbankan Islam Dan Lembaga-lembaga Terkait. Jakarta: Rajawali Press.

Syahrûr, Muhammad. 1990. al-Kitâb wa alQur'ân: Qira'âh Mu'asirah. Damaskus: alAhalli li al-Tiba'ah.

Syamsudin, Sahiron. 2004. Mempertimbangkan Metode Tafsir Muhammd Syahrûr. Yogyakarta: Forstudia Islmika. 
Syazali, Munawir. 2002. Ijtihad Kemanusiaan. Jakarta: Paramadina.

Wibowo, Edi, dkk. 2005. Mengapa Memilih Bank Syariah. Bogor: Ghalia Indonesia.
Zuhdi, Masyfuq. 1997. Mâsa'il Fiqhiyyah. Jakarta: Toko Gunung Agung. 